\title{
TTR
}

Traduction, terminologie, re?daction

\section{The Sociolinguistics of Translating Canonical Religious Texts}

\section{Eugene A. Nida}

Volume 7, numéro 1, 1er semestre 1994

Genres littéraires et traduction

URI : https://id.erudit.org/iderudit/037173ar

DOI : https://doi.org/10.7202/037173ar

Aller au sommaire du numéro

Éditeur(s)

Association canadienne de traductologie

ISSN

0835-8443 (imprimé)

1708-2188 (numérique)

Découvrir la revue

Citer cet article

Nida, E. A. (1994). The Sociolinguistics of Translating Canonical Religious Texts. TTR, 7(1), 191-217. https://doi.org/10.7202/037173ar

\section{Résumé de l'article}

La sociolinguistique de ta traduction des textes religieux canoniques - Les facteurs sociolinguistiques sont souvent négligés dans les études théoriques et pratiques de la traduction. C'est tout particulièrement le cas des textes religieux, où les problèmes de variantes textuelles, de critique historique, la puissance de la tradition, les tensions entre la forme et le contenu, l'oralité, la présentation du texte, les différents genres et les notes explicatives jouent un rôle très important. Il en résulte que de multiples traductions sont en général nécessaires en raison des différents arrière-plans des lecteurs et des utilisations des textes religieux (étude, prière, cérémonies, liturgie).
Tous droits réservés @ C TTR: traduction, terminologie, rédaction — Les auteurs, 1994
Ce document est protégé par la loi sur le droit d'auteur. L’utilisation des services d'Érudit (y compris la reproduction) est assujettie à sa politique d'utilisation que vous pouvez consulter en ligne.

https://apropos.erudit.org/fr/usagers/politique-dutilisation/ 


\title{
The Sociolinguistics of Translating Canonical Religious Texts
}

\author{
Eugene A. Nida
}

Although translating present-day secular texts can be difficult because of numerous sociolinguistic factors, translating canonical religious texts is almost infinitely more complex. But in order to appreciate the nature of these complexities, it may be strategic to define first the meanings of such key terms as sociolinguistics, translating, canonical, and religious texts.

\section{Sociolinguistics}

While linguistics focuses primarily on the structures and processes of language, sociolinguistics focuses on the use of language, that is, how and why people employ language to do things. This approach to language must be concerned with such functions as providing information, establishing and maintaining proper interpersonal relations, expressing feelings (e.g. Ouch! and Damn!), changing the social status of others (e.g. by cursing or blessing people, sentencing criminals, and solemnizing a marriage), changing the emotional state of people (by means of jokes, clever repartee, and puns), and altering the behavior of other people. These different functions, sometimes referred to as informative, interpersonal, expressive, performative, emotive, and imperative, are primarily sociolinguistic in that they relate to the use of language and not to its structure. 
It is unfortunate that this sociolinguistic perspective on translating has been so largely neglected. Most books on translation deal with the translating of literary texts, for example, Steiner's penetrating insights in After Babel (1975) and Felstiner's scholarly analysis of difficulties in Translating Neruda (1980). Most series of articles growing out of symposiums are likewise about translating literary texts, e.g. Translation: Literary, Linguistic, and Philosophical Perspectives, edited by William Frawley (1984), Translation Studies: The State of the Art, edited by Kitty M. van Leuven-Zwart and Ton Naaijkens (1991), and The Art of Translation: Voices from the Field, edited by Rosanna Warren (1989). These volumes are generally heavy on style and discourse but weak on the sociolinguistic factors.

A number of linguists have approached transiation primarily from the perspective of the differences in language structures. Some of the principal treatments of this type include A Linguistic Theory of Translation by J. C. Catford (1965), Introducción a la Traductología by Gerardo Vazquez-Ayora (1977), The Science of Translation: Problems and Methods by Wolfram Wilss (1982), and The Science of Linguistics in the Art of Translation by Joseph L. Malone (1988), which employs almost exclusively a transformational-generative orientation. Nida's early contributions (1964 and 1969) were primarily linguistic, but with considerable attention to the cultural factors in meaning. His later publications have been more sociolinguistic, e.g. Meaning across Cultures by Nida and William D. Reyburn (1981) and From one Language to another by Jan de Waard and Nida (1986). The excellent volume by Mary Snell-Hornby, Translation Studies: $A n$ Integrated Approach (1988), recognizes the need for treating translation from a wide range of perspectives, including particularly the important features of sociological settings. The most helpful introductions to sociolinguistics are the two volumes by Ralph W. Fasold, The Sociolinguistics of Society (1984) and The Sociolinguistics of Language (1990). These do not deal with 
translation as such, but contain numerous insights that are relevant to any kind of interlingual communication. ${ }^{1}$

\section{Translating}

The term translating implies both intralingual and interlingual communication. The translating of the Greek New Testament from the Hellenistic Greek of the first century to present-day Demotike Greek (something that caused the fall of the Greek government in 1913) is a case of intralingual translating. Translating, however, normally refers to interlingual communication.

By the end of 1992 at least one book of the Bible had been translated and published in 2,009 languages, representing all major language families and cultures and including fully 99 percent of the world's population. Translations of the Koran, however, are relatively limited and have often been done by non-Muslims for scholarly purposes, since Islam has traditionally been opposed to any translating of the Koran. The same is largely true of Hindu sacred writings, but somewhat less so of Buddhist scriptures, the major exception being the translation of Buddhist texts into Chinese and later into Japanese.

There are interesting sociolinguistic aspects of Bible translating for largely antiquarian purposes, e.g. the New Testament translation into Pennsylvania Dutch and another New Testament in an archaic form of Guarani in an attempt to revive the seventeenth century form of this language. There have also been dilettante motivations in favor of Bible translating, e.g. Napoleon's sponsorship of translations of the Song of Songs into a number of French dialects. But the most interesting and relevant translations have been made to serve a believing community or as a means of gaining converts. The translation of the Hebrew Bible into Hellenistic Greek, done largely in the

1. In the preparation of this article, I am especially indebted to my two colleagues, William D. Reyburn and Barclay M. Newman, for their insights about sociolinguistic factors in translation. 
second century B.C., was undertaken primarily for Jews in the Diaspora and especially in Egypt, but it also helped to make new converts to Judaism as it gained considerable influence among the so-called "God-fearing" Gentiles.

\section{Canonicity of Texts}

Canonicity, the status of certain documents as being of supreme authority for a particular constituency, has not been an issue in Islam, because only the Koran in its Classical Arabic text is canonical, although some commentaries have gained almost canonical importance for certain sects of Islam. In Hinduism and Buddhism there has never been a definitive canon of religious texts. But for Christianity, the issue of what is to be legitimately included in the Holy Scriptures is still an unsettled question, despite all the church councils and endless debates.

Prior to the fall of Jerusalem in 70 A.D., the Jewish canon included not only the thirty-nine books of the Hebrew Bible but also a number of additional books known primarily in their Greek form, the so-called "Deuterocanonical" or "Apocryphal" books such as Tobit, Judith, Wisdom of Solomon, and Sirach (written first in Hebrew and later translated into Greek). Toward the end of the first century A.D., the Jewish community insisted that only those books traditionally known in their Hebrew form constituted their official Scriptures. The Christians, however, accepted the protocanonical texts of the Hebrew Bible as well as the deuterocanonical texts, but they gradually added the twenty-seven books of the New Testament after more than a century of disagreement and debate. Protestants later rejected the deuterocanonical books as a basis for doctrine, but Lutherans and Anglicans have included, with minor differences, various deuterocanonical books in certain editions of their Bibles and liturgies. The Orthodox churches also differ with respect to the degree of authority assigned to these additional writings, with the Ethiopic Orthodox Church having the most fluid view of canonicity. 


\section{Canonicity of Translations}

The canonicity of translations means that "translating the Bible" has quite different meanings in different sociological contexts. Serious complications in canonicity arise when particular translations become canonical for certain constituencies. For example, the Latin Vulgate Bible was the canonical interpreter of the Bible text for Roman Catholicism for some 1,400 years. Similarly, for many English-speaking Protestants the King James Version has been the "authoritative text," and some biblicists have gone to great lengths to justify the King James Version by insisting on the validity of the so-called "majority text." Adoniram Judson's translation into Burmese gained a similar status for most Protestants in Burma.

Canonicity may, however, be acquired almost overnight. For example, after one translator in West Africa had completed the translation and publication of the Bible in one of the important trade languages of the area, he decided to take some courses in linguistics at a leading university in England while he was on furlough. He soon realized how many mistakes he had made in his earlier work, and so after returning to the field, he asked for permission to undertake an important revision. But his colleagues insisted that he had no right to change the Word of the Lord.

\section{Religious Texts}

The phrase "religious texts" may be understood in two quite different senses: (1) texts that discuss historical or present-day religious beliefs and practices of a believing community and (2) texts that are crucial in giving rise to a believing community. For example, commentaries on the Bible would be in the first category, but the Bible itself would be in the second category. Similarly, in the case of recent religious movements a book about present-day beliefs of Mormons would be in the first category, while the Book of Mormon translated by Joseph Smith would be in the second. This distinction may appear at first to be somewhat arbitrary, but it is fundamental to proper 
understanding of and appreciation for some of the widespread and emotion-laden sociolinguistic factors involved in the translation of the basic revelatory documents of a religious movement.

\section{Textual Variants}

Bible translators are faced not only with the issue of what books to translate but also with what edition of the Greek or Hebrew text to use as a basis for translating. There are no autographs of even a single word of the Greek and Hebrew Scriptures. Furthermore, there are many differences in the manuscripts, and it is impossible to produce a valid text by merely counting up the manuscripts that favor one or another form. Textual scholars "weigh" manuscripts rather than "count" them.

For the New Testament there are more than 5,000 manuscripts, if some of the papyri fragments are included, and at least 1,400 passages in which there are significant differences of meaning in the diverse manuscripts. In order to assist translators in determining which of the manuscript variants have the greatest probability of representing the original form of the autographs, the United Bible Societies sponsored a thorough examination of all the evidence. This was done by an interconfessional committee of leading textual scholars. The results of their work included a text of the Greek New Testament in which the validity of different manuscript evidence was rated as $A, B, C$, and $D$. The rating $A$ indicates that the words in the text, in contrast with the alternatives in the footnotes, are quite certain. The rating $B$ indicates some doubt; the rating $C$ indicates considerable doubt, while the rating $D$ means that only God knows what was in the original autographs.

For the Old Testament there are some 5,000 passages in which manuscript evidence differs and the problem of diverse meanings is relevant. There are relatively few Hebrew manuscripts, but there is a long tradition of translations. And some of these translations are so completely literal that scholars can readily determine what must have been the underlying 
Hebrew. The United Bible Societies also sponsored an interconfessional committee for the Hebrew Old Testament Text Project, and the results of this work were published in five preliminary volumes and are now in process of being published in five volumes of approximately 1,000 pages each in French.

A high percentage of the difficulties in determining what text to translate represent accidental or purposeful alterations by scribes in which the major tendency is to smooth out or level the text to fit the literary or practical context (essentially an aspect of entropy). For example, in the Gospel of Mark 1.2 the best manuscripts have "as in Isaiah the prophet," but the immediately following words actually come from Malachi and only the second part of the quotation comes from Isaiah. Some scribes must have noted this mistake and altered the introductory statement in verse 2 so as to make it read "as in the prophets."

In the Gospel of Luke 2.33 the better manuscripts have "his father and mother," but a reference to "his father" may have seemed to some scribes to call into question the doctrine of the virgin birth. Accordingly, certain scribes must have changed the Greek text to read "Joseph and his mother."

In some instances scribes tried to make sense out of a particularly difficult statement. For example, in the Gospel of John 1.18 the Greek text has literally "the only God who is in the bosom of the Father" (in which "in the bosom of" is a Semitic idiom meaning "closest to"). In view of the term "Father" being in the same context, certain scribes must have thought that the Greek term theos "God" should have been uios "Son."

\section{Interpretive Basis}

The problems of what to translate (canon and text) are by no means as complex as determining the basis for interpretation. Historical critical studies of the text are essentially of three types: literary, redactional, and canonical. In literary studies of a text, scholars generally try to go behind the existing texts to determine how and where they arose. They are also concerned to examine 
any other contemporaneous texts (often spoken of as "intertextuality") that might have influenced the form or meaning. Some scholars, for example, insist that it is impossible to understand the meaning of the Psalms without knowing the meaning of parallel expressions in Ugaritic, a Semitic language closely related to Hebrew. To a certain extent the evidence from Ugaritic texts is important, but what is far more decisive for a Bible translator is precisely how such expressions were used and understood when they occurred in Temple worship in Jerusalem.

The Hebrew expression ruah elohim in Genesis 1.2 may mean "a strong wind," because ruah can mean "wind" (as well as "breath" and "spirit") and elohim, generally the Hebrew word for "God," can also indicate an emphatic degree of something, e.g. Nimrod is called literally "a hunter of God," meaning "a great hunter." "The real question, however, is what the expression ruah elohim actually means in Genesis 1.2. Should one assume as the interpretive basis the meaning of such a phrase in its earliest oral usage? Or should one be concerned with its meaning when it was used in Temple worship in Jerusalem? In this latter case the phrase would evidently be better rendered in Genesis 1.2 as "Spirit of God."

The history of editing an ancient text (often called "redaction") further complicates a translator's task. A final text may represent more than one stage of editing and more than one source, each with its distinctive terminology. Are such differences really important? Or are they only alternative ways of saying essentially the same thing? For the Hebrew Old Testament many of these differences are related to the so-called "Documentary Hypothesis" about different sources combined in the standard text.

Canonical studies add a further dimension to the task of translators, because they must also view the meaning of a text from the interpretive position of the believing community that has accepted the authenticity of the text and has taken seriously the meaning of the text for their own beliefs and practices. But over a period of several thousand years believers may acquire 
radically different views about the value and relevance of certain books. For example, Judaism has traditionally interpreted the Song of Songs as a poem about the relation of God to Israel, while Christians have viewed it as an allegory about the relation of Christ to the church. Most present-day scholars, however, view the Song of Songs as a wedding song and a remarkable tribute to romantic love. But what are translators to do when even the best scholars differ with one another? Should they adhere to the "party line" of their own religious constituency, which they are often forced to do, or should they attempt to seek neutral (and even ambiguous) renderings? How many of these differences should be included in footnotes? And should the history of such differences be highlighted or even mentioned?

\section{The Power of Tradition}

Anyone who retranslates a text is usually well aware of what one or two predecessors have done, but a Bible translator has some 2,000 years of translators looking over his or her shoulder. Even when an expression is almost totally incomprehensible to an audience, there is strong pressure to retain traditional formulations. For example, almost no lay person understands the meaning of the first petition in the Lord's prayer. What does "Hallowed be thy name" really mean to most English-speaking persons? The Greek text has literally "May your name be sanctificd" or "...be made holy." But how can God's name be sanctified or made holy, when God himself is regarded by the biblical authors as the essence of holiness? Furthermore, the use of "name" is simply a Semitic way of referring to a person. This first petition must refer somehow to the manner in which people should recognize the holiness of God, and accordingly one may translate this request as "Help us to honor your name" or "May everyone recognize you as God."

A similar problem exists in the first beatitude, "Blessed are the poor in spirit." The term translated "blessed" is the Greek word makarios, which in many contexts means simply "happy" or "fortunate." But the term "happy" would trivialize the meaning of the text, and "fortunate" seems too close to "lucky." The Greek 
term makarios is the regular way of talking about the blessed state of the Olympian gods, and in this context of divine blessing in the Gospel of Matthew there is a literary echo to Psalm 1.1, which in the Septuagint Greek translation also begins with makarios. The religious dimension of this word suggests the English term blessed. But there is an additional problem with the passive use of blessed. Throughout the beatitudes there is a calculated use of the passive as a typical means of avoiding a direct reference to God as the agent (a case of positive taboo). And so in complete fairness to the Greek text, the Contemporary English Version translates "God blesses those people who depend only on him." But it is also possible and acceptable to employ a translation such as "Fortunate are those who recognize their need of God." In order to be faithful to the meaning of the Greek text, a translator must avoid a rendering such as "poor in spirit," which suggests to most people a lack of ambition or even pathological uncertainty.

\section{Form and Content}

For the English-speaking world the relation between form and content in Bible translation is exceptionally strong because of the widespread use of the King James Version for several hundred years and the incorporation into English literature of hundreds of quotations from that version, even more than from the plays and poems of Shakespeare, as is clearly noted in the Kenkyusha Dictionary of English Quotations (1965). Furthermore, for many present-day speakers of English the old-fashioned terminology and grammar of the King James Version have acquired such a distinctive "flavor" that modern Bible translations are sometimes rejected as not even being the Bible. For example, upon reading the Good News Bible for the first time, a high school girl exclaimed to her mother, "This must not be the Bible; I can understand it."

In some instances people reject intelligible content since the aura of mystery, so typical of religious experience, seems to be lost.In fact, one Guatemalan Indian translator of the New Testament objected to detailed explanations of the meaning of the biblical text, because, as he insisted, if the meaning becomes too 
clear, it will no longer be religion. The mystery of faith should not be equated with the unintelligibility of words. One of the distinctive features of all religious language is its nebulous semantics, because people attempt to talk about infinite, absolute truths by means of finite, culture-dependent words.

When religious language is completely obscure, as Latin was for most people in Northern Europe, certain solemn utterances may degenerate into magic formulas. The crucial Latin expression in the mass, Hoc est enim corpus meum "This is my body," was not understood, but it did form the basis for hocus pocus, sometimes with the added skewed Latin dominocus to balance the first four syllables and complete the rhythmic assonance.

In some instances people may prefer to retain a special form of religious language as a marker of in-group identification. For example, some twenty years ago Baptists in Russia were strongly urged to undertake a revision of their antiquated Bible, but they politely refused to do so and insisted that in their worship services and even in some of their social contacts they preferred to keep the distinctive language of their Scriptures. When urged to explain such a seemingly strange attitude, they revealed that it normally took a new convert a year or more to master this archaic, specialized form of language, and by that time it would be clear whether such a person was actually a member of the KGB.

Some people object to Bible translations that reflect the type of language used in newspapers, because they have such a low regard for the truthfulness of newspaper reporting. Others object to the use of present-day slang, because it seems to be so anachronistic and too ephemeral. Bible translations on a level of substandard usage are almost always rejected, even by those who customarily use such language. Such persons regard these translations as being paternalistic put-downs.

Translations can, however, have such a high level of language as to convince readers that the message is obviously not 
for them. Some of the high-level terminology in the New English Bible, e.g. effulgence, purgation, ministrant, and requite, has seriously restricted the acceptance of this otherwise excellent translation.

More serious than the use of high-level language is the tendency to employ the same level of language throughout the entire Bible. Furthermore, many translators assume that since the original text was inspired by the Holy Spirit, it should be translated on a level that will correspond to the sublime character of the contents, and so the simple, straightforward language of the Gospel of Mark is made to sound like the elaborate language of the Epistle to the Hebrews.

Recently, still another sociolinguistic factor complicates the translator's task, namely, the insistence on "gender neutral language" as a corrective to the evident male-dominant languageculture of the biblical text. Some persons object to using the pronoun he in referring to God and prefer to repeat the term God in every instance, even though the results suggest a number of Gods. Other persons wish to have God referred to sometimes as he and in other contexts as she so as to avoid a seemingly chauvinistic theology and to make deity gender neutral. In many cases, however, the result has been to make deity bisexual, with all the attendant implications of fertility cults. There is, however, complete justification for using people rather than the traditional men as a generic reference to both men and women, for employing plural reference (e.g. they instead of he and she), and for shifting from third person to second person (e.g. you instead of an indefinite anyone, which often requires an awkward singular anaphoric reference, he or she).

Some attempts to provide neutral language result in anachronisms and cultural absurdities. In one instance a committee expanded the biblical reference "Abraham our father" to "Abraham our father and Sarah and Hagar our mothers." But what about Keturah, who was later married to Abraham? Putting a wife and a servant into the same category is not only culturally strange, but would surely offend those Jews who regard Hagar's son Ishmael as the progenitor of Arabs. 


\section{Literalness}

The most crucial question about the translation of religious texts involves the degree of literalness. This was the principal issue among scholars in the classical world and was the crucial problem in the early Latin-speaking church. Was the church in the Western part of the Roman Empire to use the rigidly literal translations in the Old Latin tradition or Jerome's Vulgate translation prepared in the language of the common people, the vulgus?

Preference for literal translations of the Bible may involve a number of factors. In the first place, people may only be acquainted with more or less literal translations, and therefore these represent an implicit norm. In the second place, the experience of studying foreign languages in school may suggest that only literal renderings are translations and that free renderings are paraphrases. Because of having to translate foreign texts literally in school, many people assume that such translations are not only preferable, but actually closer in meaning to the original.

Some people mistakenly assume that if the Bible is inspired by God, then it should not sound like normal language. In a sense, this reaction is not far removed from the thought of ancient Hebrews, who placed high value on the poetic language of the prophets. Not only was the poetic form more rememberable, but its very distinctiveness marked it as somehow "inspired."

Some persons prefer literal translations because they assume that in any inspired text there are likely to be a number of different hidden meanings lurking behind the words. Accordingly, a literal translation would presumably preserve all these possible meanings, while a free translation would be more likely to suppress some of the possible interpretations.

Other people like literal translations that are particularly difficult to understand because a preference for such expressions 
is proof of their extra measure of faith in believing the unbelievable. The very mystery of such anglicized Latin words as predestination, propitiation, expiation, sanctification, and justification seems to enhance enormously the eternal verity of the verbal message.

Literalism can also be dangerously misleading. For example, the biblical idiom "Give God the glory" (Gospel of John 9.24) really means "Swear to tell the truth." It seems quite clear to most people that the future is ahead and the past is behind, but some Quechuas argue that the past is ahead and the future behind. They insist that what one can see in the eyes of the mind is the past, which must be ahead, and the future, which cannot be seen, must be behind.

Sometimes common words are so changed in meaning that they can no longer be employed in translations, even though they may be quite popular with certain believers. The English term justify normally means attempting to make something appear right even when it is basically wrong, and although it was at one time a more or less satisfactory translation of the Greek term dikaioo, it certainly is misleading today. Even the rendering of the Greek term logos as "word" is seriously misleading in English, as well as in many other languages, because this usage seems to make the Bible "the words of God." One African leader was so disappointed with the quality of the translation of the New Testament into his language that he concluded that God had obviously not learned the local language. The Greek language has two other terms, epos and rhema, which can both be properly translated as "word" or "speech," but logos refers primarily to the "content of a message" and not to the verbal vehicle.

In some instances it is the literalness of the grammar that is so misleading. The statement in the Epistle to the Romans 1.17 "The righteousness of God is revealed from faith to faith" is misunderstood by practically all lay people and by many preachers. They do not realize that the phrase "the righteousness of God" is not a reference to God's personal character, but to his 
activity in "righting wrong" or in "putting people right with himself," that is, in "making them acceptable." Furthermore, the phrase "from faith to faith" is not a reference to levels or kinds of faith, but to the fact that faith is the requisite for what God does. Compare the rendering in Today's English Version, "...how God puts people right with himself: it is through faith from beginning to end." Some people, however, object to such a rendering because it scems to preempt the role of preachers, who with such an understandable text would have no need to interpret the Greek text in their sermons.

Unfortunately, some attempts at literal translating fail in almost every way. They are misleading or strangely unintelligible, and they add elements that do not belong to the context. Note, for example, two short passages in Chouraqui's rendering of the Gospel of Matthew 4.10b and 5.3, both of which are quotations from the Hebrew Bible.

\section{Matthew 4.10b:}

English: Worship the Lord your God and serve only him. French: Prosterne-toi en face de IHVH [adonai], ton Elohim sers-le, lui seul.

The Greek term proskuneo can mean "to prostrate oneself," but in the context of worship, the French expressions adorer and rendre culte would be far more appropriate. Chouraqui's use of Prosterne-toi en face de is a misleading literalism. The use of $I H V H$ [adonail is an attempt to relate the Greek term kurios to the Hebrew Yahveh, normally translated in English as Lord or LORD, but not pronounced in Hebrew. In place of the divine name (often called the tetragrammaton) Hebrew speakers substituted another Hebrew word adonai, which was indicated in the Hebrew text by the use of vowel diacritics but without any change in the consonants. By placing $I H V H$ in one clause and Elohim (the normal Hebrew word for God) in another clause, the reader or hearer could get the impression that the original text makes some kind of distinction. But the Greek text has a composite title, the Lord your God. 


\section{Matthew 5.3:}

English: Blessed are the poor in spirit

French: En marche, les humiliés du souffle! Oui, le royaume des ciels est à eux!

Chouraqui's rendering of Matthew 5.3 is also a curious blend of literalism and radical reinterpretation. The expression $d u$ souffle, literally "of breath" or "of spirit," is an attempt to represent the Greek term pneuma, which can mean "breath," "wind," or "spirit." But les humiliés "the humiliated ones" means reading into the Greek term ptochos "poor" more than the text is really saying. Such an interpretation does, however, reflect certain present-day sociological reinterpretations. And finally, the phrase en marche can be rendered as "take heart" or "get going," but this is simply not in the original text, nor is it implied. There is also a discordant discourse element. The first sentence seems to suggest direct address with a second person reference, but the second sentence shifts to third person.

A particularly subtle and misleading aspect of the Bible text is the frequent use of numbers having symbolic meanings. The numbers seven, twelve, and forty are particularly misleading. The number seven suggests perfection in a number of contexts, while the number twelve frequently refers to something complete, and forty is often employed to indicate a relatively long period of time. The symbolic meanings of seven and twelve are espccially important in the Book of Revelation with its seven churches, seven seals, seven bowls of wrath, and seven trumpets, as well as its twelve gates, twelve foundation stones, twelve stars, twelve apostles, and twelve kinds of fruit. The three periods of forty ycars in Moses's life are interpreted by many scholars as referring to relatively long stretches of time, and not necessarily to exactly forty years. In some contexts the number 1,000 is particularly misleading, because the Hebrew term may also refer to a herd of cattle or to a relatively large group of biologically related people, namely, a clan or tribe. Some scholars, therefore, have suggested that in some contexts this Hebrew term eleph 
should be understood in the more generic sense of a considerable number rather than specifically one thousand.

When symbolic numbers are transformed into another system, much of the significance of a passage may be lost. For example, the "twelve thousand stadia" of the Greek text in the Book of Revelation 21.16 become "one thousand five hundred miles" as the measurement of the new Jerusalem coming down from heaven whether a cube or a pyramid, the text does not indicate. For the ancient world twelve thousand stadia (approximately the distance between Jerusalem and Rome) implied a tremendous size, but one that had primarily symbolic meaning. Much of this symbolism is lost in a translation specifying "one thousand five hundred." This is surely a point at which some explanatory note is indispensable.

\section{Orality}

Orality of a canonical religious text is significant on two distinct levels: (1) the oral character of the original revelation and (2) the fact that the contents of such religious documents are heard more often than they are read by a believing constituency. This is particularly true of Judaism, Christianity, and Islam. The earliest traditions in the Bible were certainly passed on orally for a number of generations before they were written down, and in the Hebrew Bible a good deal of this oral tradition can be readily seen in the plays on the meanings of words, the various popular etymologies for proper names (sometimes more than one such etymology), and the measured lines in prophetic utterances. Liturgical sections in the Greek New Testament exhibit elaborate oral parallelism. In the Matthaean form of the Lord's Prayer the first five lines in the Greek text consist of nine syllables each, and the last five lines, which are thematically quite different, have a pattern of 15-12-15-12-12 syllables.

In order to avoid misleading sequences in the aural comprehension of a text and in order to facilitate proper understanding and appreciation of the aural form of a discourse, a translator must be constantly on guard against misperceived 
meanings, as, for example, in the Gospel of Matthew 2.9 "The wise men listened to what the king said, and then left. The star they had seen in the east went on ahead of them until it stopped over the place where the child was." A failure to mark the end of the first sentence with a sufficient pause-pitch will lead people to hear the transition as "[...] and then left the star they had seen in the east [...]" Or consider a near mistake in one translation, in which the oral form of an early draft was completely misleading, e.g. "Take us back to the land, Lord." The last two words would certainly have been heard by most people as "landlord."

Since canonical religious texts are often read antiphonally or in unison, it is particularly important in English for persons to easily recognize the placement of the phrase stress, and not merely the proper word stresses. But if a text has more than three potentially unstressed syllables in a row, many readers are confused as to where the phrase stress should occur. As a result, an audience becomes frustrated and the results are aesthetically impoverished.

\section{Format}

In order to assist readers in understanding the contents and appreciating the formal features of a text, it is often important to mark various units by certain distinctions in format. These distinctions are essentially equivalent to the paralinguistic and extralinguistic features of oral language, but they take on a more serious symbolic meaning because they are "in black and white" and thus seem to mark more dramatically the differences in major traditions.

In order to mark the shifts of speakers in conversations or dialogue, separate paragraphs are extremely useful, but some readers object to such arrangements because they mistakenly think that this makes the text look too much like a novel or newspaper report and in this way suggests that the contents of the text are either fictional or purely secular. 
The use of indentation for poetic lines is especially important in order to indicate primary and secondary elements in parallelism. Furthermore, poetic lines immediately suggest that the text is likely to be highly figurative and symbolic. But some readers object to poetic lines in the Bible because they believe that anything in a poetic format is not likely to be true. In fact, the translator of one important Bible into English paid considerable attention to the poetic structure of Hebrew poetry, but printed his translation as prose so that people would be assured of its truth. Some people, however, prefer the distinct marking of poetry by measured lines because they believe that in this way they can distinguish between what comes from God (namely, the prose) and what has just been made up by people (the poetry). This is, of course, precisely the opposite of the values associated with poetry in Ancient Hebrew, where something in poetic form achieved greater authority because of its distinctive vocabulary, structure, and rhythm.

One serious problem of format has greatly impaired the understanding of traditional translations of the Bible, namely, the more or less arbitrary way in which chapter and verse divisions have been made. For some people the printing of each verse as a separate unit is a mark of orthodoxy, and Bibles that employ any other format are regarded as theologically suspect.

Even the number of columns on a page can be an important symbol of authenticity for some people. For example, single-column editions are often suspect, because they suggest that the Bible is nothing more than just another book.

Some persons insist on different sizes and styles and colors of type to set off certain texts and sections. For example, many want the words of Jesus to be printed in red, but in some cases scholars cannot agree as to what part of a text represents the words of Jesus and what part consists of comments by the Gospel writer. Other persons believe that all fulfilled prophecy must be marked in some special manner, and still others want theologically important verses printed in bold type. All of these distinctions actually undermine the doctrine of plenary 
inspiration, but this fact seems not to have been recognized by the proponents of such distinctions.

In addition to differences of form and style of type, there is often the issue of the orthographic system. For example, linguists who only know something about phonetics and phonemics and practically nothing about graphemics have sometimes insisted on strict one-to-one correspondences between letters and sounds, only to discover that reading is a much more complex phenomenon than they had earlier imagined. Furthermore, the influence of a dominant national or trade language may force orthographic accommodations. For example, in some of the Indian languages of Latin America that have palatial and velar series of stop consonants, it would be very practical to write the palatial series with $k$ and the velar series with q, but the pressure of Spanish is so great that one is usually obligated to use $c$ and $q u$ for the palatal series and $k$ for the velar.

The fact that the Taiwanese Bible was written in an adaptation of the Roman alphabet made the translation politically suspect when the mainland Chinese took over the island. One of the points of contention between the north and the south of Sudan is the different way in which people write their own languages. The southerners are severely criticized by many in the north simply because they insist on using the Roman alphabet to write their Nilotic languages.

One of the particularly crucial issues that divide Jews, Roman Catholics, and Protestants is the order and arrangement of Old Testament books. Jewish publications distinguish between the Law, the Prophets (including the earlier and the later prophets), and the Writings, which include the wisdom literature as well as the books of Daniel and First and Second Chronicles.

Roman Catholic editions of the Old Testament follow primarily the order of the Septuagint Greek translation, in which the so-called deuterocanonical books are dispersed among the books of the Hebrew Bible. Most Protestant Bibles not only reject 
the deuterocanonical books, but generally have the order of the four main categories: the Pentateuch, the historical books, the wisdom literature, and the prophets. For most scholars these differences seem trivial, but for some people altering a traditional order of books is tantamount to heresy.

\section{Supplements to the Text}

In view of such problems as text, alternative interpretations, crucial historical background data, cultural differences, and important similarities and differences between different books and even parts of the same book, a number of supplements to the text are usually regarded as indispensable: marginal notes, introductions to the various books and related sets of books, and appendices, including maps, word lists, and indices.

Notes are especially important in pointing out similarities (e.g. parallel passages) and contrasts (e.g. the fact that in the New Testament so many of the quotations from the Hebrew canon are actually from the Greek Septuagint translation rather than from the Hebrew text). In fact, in some instances the New Testament quotes the Old Testament in a manner that is completely contrary to the Hebrew. For example, in Epistle to the Hebrews 1.7 the text reads, "God makes his angels winds, and his servants flames of fire," but the Hebrew text of Psalms 104.4 has "God makes the winds his messengers and the fiery flames his servants."

Differences of text and interpretation are inevitable. In the Gospel of John 1.9 the King James Version has "the true light which lighteth every man that cometh into the world." This can be readily understood as a confirmation of important Gnostic ideas. The more contextually valid rendering of this passage is "On coming into the world, the true light shines on all people."

In order to understand better the historical context of the Bible, most people need to know something about the time of the exodus from Egypt, the different Herods mentioned in the New Testament, and the fact that most of the letters of the New Testament were written before the Gospels. For the Hebrew Bible 
it is particularly crucial to have cultural data about the Urim and Thummim, temple prostitution, holy wars, and nazirite vows.

Without adequate introductions to various books and groups of books, readers find it very difficult to understand the apocalyptic literature of the prophet Daniel and the Book of Revelation. They are dismayed by the skepticism in the Book of Ecclesiastes and are surprised by the erotic language in the Song of Songs. They are also disturbed by the differences in the Gospels, and the many strange geographical names confuse readers about the places where events took place. A good set of maps for different historical epochs is indispensable.

Not only are indices extremely helpful, but the same is also true for a table of contents and a preface that explains to readers the textual basis and the exegetical perspective, as well as the principles and procedures employed by the translators.

\section{Varieties of Translation}

No single translation of the Bible in a major language is likely to represent adequately the diversities of horizontal, vertical, and religious-political dialects. This means that multiple translations are inevitable, especially in areas where there are numerous geographical (horizontal) dialects of languages not previously reduced to writing and for which no local trade language is adequate to communicate the contents of a religious text. In the past, missionaries have sometimes exaggerated the differences between dialects because they have never thoroughly mastered any one dialect. But even speakers of local dialects often tend to exaggerate their own distinctive dialectal features for the sake of political recognition. In Nigeria speakers of two closely related dialects of Ijaw insisted that their languages were mutually unintelligible, even though they had no difficulty arguing vigorously with each other about the impossibility of understanding one another's dialect.

Some missionary translators have attempted to solve the problems of related horizontal dialects by undertaking a 
linguistically "unified dialect." In some instances this has worked quite well, especially if highly competent persons have been able to choose the most widely acceptable terminology and have used the grammatical apparatus of a central dialect. But in some cases translators have tried to follow a "democratic method" and have more or less arbitrarily chosen first one form and then another in order to be seemingly fair to everyone. The results have usually been a disaster, and the local people complain that "Nobody ever talks that way."

Vertical dialects are those important sociolinguistic dialects that exist in all large, complex societies. For the most part there are three major vertical dialects: (1) the language of traditional literature and education, (2) an overlap language between the literary standard and colloquial usage, often called "the common language" or "a koine form of language," and (3) a strictly colloquial level of language, known by almost everyone, but only employed by certain marginal socioeconomic classes or ethnic groups. This third level of language is often regarded as "substandard" and hence "wrong." It is, however, a very important symbol of class membership.

Most translations made for an in-group tend to employ a high-level language based on traditional literary standards, but translations prepared for people outside of the believing community are usually based on a more popular form of language, while avoiding substandard forms with negative aesthetic values. Some translations are purposely "old fashioned" in words and grammar, since an older generation often identifies much more readily with something that sounds familiar. At the same time the antiquarian nature of the vocabulary makes the text seem closer to the time when the original texts were first written.

In addition to these three major vertical dialects there are certain other rather distinct forms of language, e.g. the language of small children, the forms of language habitually employed by non-native speakers, and distinct ethnic forms of a language (for example, Black English in the United States). Some scholars insist 
on even further distinctions, for example, the language of the deaf, the languages employed in multimedia editions, the language of the theatre or of comic strips, and the language of song and opera. But most of these distinctions are essentially differences of discourse rather than of language.

Religious-political dialects are especially arbitrary and at the same time strongly resistant to change or compromise. For example, in the early 1970 's there was a widespread hope that Roman Catholic and Protestant Chinese scholars might be able to work out plans for a joint translation of the Bible in Chinese. The principal obstacle to such a joint endeavor was the writing of proper names. Earlier Roman Catholic translators had generally followed the Italian or Latin forms of proper names, while Protestant translators had usually employed English or Greek and Hebrew for the selection of corresponding Chinese characters. But even in those instances in which the pronunciation was the same, Roman Catholics had purposely chosen Chinese characters that were different from those selected by Protestants. The emotive significance of these different forms of proper names was so strong that after one week's consultation both sides agreed that collaboration was impossible at that time. Later, however, this stumbling block to cooperation was overcome, and extensive interconfessional collaboration has been extremely fruitful.

These religious-political dialects may be based on various types of features: (1) the rendering of key theological concepts, e.g. justification, redemption, eucharist, priest, (2) pronouns used in addressing God, e.g. thou vs. you, and (3) traditional vs. "gender neutral" terminology. The tensions engendered by distinctions in religious-political dialects are usually inversely proportionate to the real importance of the differences. Largely arbitrary differences always seem to produce the most entrenched attitudes.

The translation of canonical religious texts is certainly more sociolinguistically complex than any other type of translating because of the long history involved in such 
translating, the strong emotional attachments to vocabulary and style, the political implications for deviating from tradition, and the vast differences of culture between the original revelation and its present-day interpretation and use. The task of interlingual communication is both challenging and endless. New discoveries and insights about the forms and meanings of ancient texts and about the constant changes occurring in modern languages mean that neither a timeless nor a perfect translation will ever be produced, but the goal of a truly meaningful and widely acceptable translation will continue to be a translator's "holy grail."

American Bible Society

\section{References}

ALAND, Kurt, Matthew Black, Carlo M. Martini, Bruce M. Metzger, and Allen Wikgren, eds. (1983). The Greek New Testament, Third Edition (Corrected). Stuttgart, United Bible Societies.

CATFORD, J. C. (1965). A Linguistic Theory of Translation. London, Oxford University Press.

FASOLD, Ralph (1984). The Sociolinguistics of Society. Cambridge, Mass., Blackwell.

Mass., Blackwell.

(1990). The Sociolinguistics of Language. Cambridge,

FELSTINER, John (1980). Translating Neruda: The Way to Macchu Picchu. Stanford, Calif., Stanford University Press.

FRAWLEY, William, ed. (1984). Translation: Literary, Linguistic, and Pphilosophical Perspectives. Newark, University of Delaware Press. Greek New Testament. 
MALONE, Joseph L.(1988). The Science of Linguistics in the Art of Translation. Albany, State University of New York Press.

NIDA, Eugene A. (1964). Toward a Science of Translating. Leiden, E. J. Brill.

, and William D. Reyburn (1981). Meaning across Cultures. Maryknoll, New York, Orbis Press.

, and Charles R. Taber (1969). The Theory and Practice of Translation. Leiden, E. J. Brill.

PERGNIER, Maurice (1993). Sociolinguistique de la traduction. Lille, Presses universitaires de Lille.

SANKI, Ichikawa, Masami Mishikawe, and Mamoru Shimizu, eds. (1965). Kenkyusha Dictionary of English Quotations. Tokyo, Kenkyusha.

SNELL-HORNBY, Mary (1988). Translation Studies: An Integrated Approach. Amsterdam and Philadelphia, John Benjamins.

STEINER, Ceorge (1975). After Babel: Aspects of Language and Translation. London, Oxford University Press.

VAN LEUVEN-ZWART, Kitty M., and Ton Naaijkens, eds. (1991). Translation Studies: The State of the Art. Amsterdam, Rodopi.

VAZQUEZ-AYORA, Gerardo (1977) Introducción a la Traductologia. Washington, D.C., Georgetown University Press.

WAARD, Jan de, and Eugene A. Nida (1986) From one Language to another. Nashville, Thomas Nelson.

WARREN, Rosanna, ed. (1989). The Art of Translation: Voices from the Field. Boston, Northeastern University Press. 
WILSS, Wolfram (1982) The Science of Translation: Problems and Methods. Tubingen, Gunter Narr.

\begin{abstract}
The sociolinguistics of Translating Canonical Religious Texts - Discussions of the theory and practice of translating have largely neglected the sociolinguistic factors in translating. This is particularly true in the case of religious texts, in which problems of textual variants, historical criticism, the power of tradition, the tensions between form and content, orality, format, diversities of genres, and interpretive notes play such an important role. As a result, multiple translations of such texts are generally required because of the diverse backgrounds of readers and the various uses of religious texts, for example, study, devotion, proclamation, and liturgy.

RÉSUMÉ: La sociolinguistique de la traduction des textes religieux canoniques - Les facteurs sociolinguistiques sont souvent négligés dans les études théoriques et pratiques de la traduction. C'est tout particulièrement le cas des textes religieux, où les problèmes de variantes textuelles, de critique historique, la puissance de la tradition, les tensions entre la forme et le contenu, l'oralité, la présentation du texte, les différents genres et les notes explicatives jouent un rôle très important. Il en résulte que de multiples traductions sont en général nécessaires en raison des différents arrière-plans des lecteurs et des utilisations des textes religieux (ćtude, prière, cérémonies, liturgie).
\end{abstract}

